\title{
3.0-T Diffusion Images After Clipping of Middle Cerebral Artery Aneurysm
}

\author{
Orta Serebral Arter Anevrizmasi Klipslenmesi Sonrasinda 3,0 T \\ Difüzyon Görüntüleri
}

Yasuo MURAI ${ }^{1}$, Koji ADACHI ${ }^{1}$, Fumihiro MATANO ${ }^{1}$, Ryo TAKAGI $^{2}$, Yasuo AMANO ${ }^{2}$, Shiro KOBAYASHI ${ }^{3}$, Takayuki KITAMURA ${ }^{1}$, Akira TERAMOTO ${ }^{1}$

${ }^{1}$ Nippon Medical School, Department of Neurosurgery, Tokyo, Japan

${ }^{2}$ Nippon Medical School, Department of Radiology, Tokyo, Japan

${ }^{3}$ Chiba Hokuso Hospital, Nippon Medical School, Department of Neurosurgery, Chiba, Japan

Corresponding Author: Yasuo MURAI / E-mail:ymurai@nms.ac.jp

\begin{abstract}
AIM: Replacement of aneurysm clips or temporary parent artery occlusion during aneurysm clipping (AC) carries the risk of inducing postoperative neurologic deficits. When studying the risk of surgical complications associated with cerebral aneurysms, patients with similar conditions should be compared to eliminate the influence of rupture and location of aneurysm.

MATERIAL and METHODS: We used 3.0-Tesla (3.0T) magnetic resonance diffusion-weighted imaging (DWI) and magnetic resonance angiography (MRA) to analyze surgical complications after AC. A total of $42 \mathrm{AC}$ procedures for 40 unruptured and 2 delayed-phase ruptured MCA aneurysms were evaluated.

RESULTS: In six patients, temporary parent artery occlusion was performed. Asymptomatic hyperintensities were observed on DWI of three patients. In one patient, an asymptomatic lesion was most likely caused by a small contusion that occurred during dissection of an aneurysm attached to the brain surface. In two patients, asymptomatic cortical lesions were caused by brain surface contusions due to lacerations of the open dura. No symptomatic hyperintensities on DWI were observed after surgery. No fixed ischaemic neurologic deficits resulted from AC.

CONCLUSION: Although some postoperative abnormalities were observed with 3.0T DWI, we found clipping of MCA aneurysms to be a safe procedure with a low risk of ischaemic complications.
\end{abstract}

KEYWORDS: Cerebral aneurysm, Clipping, Complications, Ischemia

öz

AMAÇ: Anevrizma klipsleme sırasında geçici ana arter oklüzyonu veya anevrizma klipslerinin yerleştirilmesi postoperatif nörolojik defisitlere neden olma riski taşır. Serebral anevrizmalarla ilişkili cerrahi komplikasyonlar riskini çalışırken benzer durumları olan hastalar anevrizma rüptürü ve konumunun etkisini ortadan kaldırmak üzere karşılaştııılmalıdır.

YÖNTEM ve GEREÇLER: Anevrizma klipsleme sonrasında cerrahi komplikasyonları analiz etmek için 3,0 Tesla (3,0 T) manyetik rezonans difüzyon ağırlıklı görüntüleme (DWI) ve manyetik rezonans anjiyografi (MRA) kullandık. Toplam olarak 40 rüptüre olmamış ve 2 gecikmiş faz rüptüre MCA anevrizması için 42 anevrizma klipsleme işlemi değerlendirildi.

BULGULAR: Altı hastada geçici ana arter oklüzyonu yapıldı. Asemptomatik hiperintansite üç hastada DWl ile görüldü. Bir hastada asemptomatik bir lezyonun beyin yüzeyine tutunmuş bir anevrizmanın diseksiyonu sırasında oluşan bir küçük kontüzyon nedeniyle gelişmesi muhtemeldi. İki hastada, asemptomatik kortikal lezyonlar açık dura laserasyonu sonucunda beyin yüzeyi kontüzyonları nedeniyleydi. Cerrahi sonrasında DWI ile semptomatik hiperintansite gözlenmedi. Anevrizma klipsleme sonucunda herhangi bir sabit iskemik nörolojik defisit oluşmadı.

SONUÇ: 3,0 T DWI ile bazı postoperatif anormallikler görüldü ama MCA anevrizmalarının klipslenmesinin düşük bir iskemik komplikasyon riskiyle güvenli bir işlem olduğunu saptadı.

ANAHTAR SÖZCÜKLER: Serebral anevrizma, Klipsleme, Komplikasyonlar, İskemi

\section{INTRODUCTION}

Although $\mathrm{AC}$ is performed to decrease the risk of subarachnoid hemorrhage (SAH), these procedures can sometimes cause temporaryor permanent neurological deficits $(10,13,24,26,36)$. Most neurological complications that occur during or immediately after $A C$ are reported $(3,17,20,23,24,25,36)$ to result from cerebral ischemia caused by $A C$ or temporary parent artery occlusion. Symon et al (32) and Mizoi et al (23) reported that the risk of temporary parent vessel occlusion are differ from the location of an aneurysm. Additionally, bias as a result of treatment strategy should also be considered. In our hospital, endovascular treatment is never used for the 
management of MCA aneurysms. Therefore, to eliminate the influence of the location of aneurysm, treatment strategy, and rupture or not, we elected to evaluate only unruptured or delayed-phase ruptured MCA aneurysms in this study.

Recent developments $(2,4,7,8,12,14,15,16,18,19,28,26)$ in MRI technology have greatly improved the quality and rapidity of cerebral ischemia diagnosis. Studies involving coronary artery bypass graft surgery (22), carotid endarterectomy $(1,35)$, or interventional surgery $(5,8,10,13,21,27,34)$ have demonstrated new small ischemic brain lesions using DWI. To the best of our knowledge, no similar studies have been conducted to assess the value of 3.0-Tesla (3.0T) DWI for demonstrating new ischemic lesions after $A C$.

\section{SUBJECTS and METHODS}

\section{Patient Selection}

Between May 2008 and April 2012, we performed 89 surgeries for cerebral aneurysms. These procedures included 42 clippings for 40 unruptured and 2 delayed-phase ruptured MCA aneurysms in 14 men and 26 women (mean age, $56.35 \pm$ 8.7 years; range, 35-77 years). There were two delayed-phase cases for which preoperative MRI and MRA were performed within one week prior to clipping. In these two patients, the period between aneurysm rupture and clipping was 17 days and 32 days, respectively, with no ischemic lesions confirmed by preoperative DWI. The aneurysms were 3-14 $\mathrm{mm}$ in diameter (mean, $5.4 \pm 0.70 \mathrm{~mm}$ ). The procedures were preceded by and followed by 3.0T DWI and MRA. In all patients, AC was performed by the author (YM). MCA aneurysms in all patients were diagnosed by three-dimensional computed tomography angiography (CTA) or MRA. Age, sex, aneurysm size, duration of temporary parent artery occlusion and the number of aneurysmal clips were assessed. Indications for surgery of unruptured aneurysms are based on the following Japanese Guidelines for the Management of Stroke 2009: 1) life expectancy $>15$ years, 2) aneurysm size $>5 \mathrm{~mm}$ or 3 ) aneurysm size $<5 \mathrm{~mm}$ in addition to irregular shape, multiple lesions, large dome/neck ratio, family history or anterior communicating artery aneurysm or internal carotid artery to posterior communicating artery aneurysm. In our hospital, the surgical indications for clipping of unruptured MCA aneurysms included the following: 1) aneurysm size $>4 \mathrm{~mm}$ or an additionally discovered unruptured MCA aneurysm in patients with an ipsilateral anterior circulation aneurysm, 2) age <75-years, 3) no serious underlying disorders and 4) a modified Rankin scale score of 0 to 2 . There are no differences in the indications for MCA bifurcation aneurysms and MCA to lenticulostriate artery bifurcation aneurysms at our institute.

\section{Surgical Techniques}

Although specific techniques or approaches for clipping MCA aneurysms differ slightly between centers, the basic principles remain the same. Special care was taken to avoid ischemic complications such as emboli formation, vasospasm and kinking of the parent artery. The duration of the parent artery temporary occlusion and perforators from the M1 segment of the MCA and the atherosclerotic M1 segment with temporary clips was minimized. To prevent venous infarctions and brain swelling, special care was taken to avoid sacrificing of the superficial Sylvian vein. Yasargil aneurismal titanium clips (Aesculap, Inc., Central Valley, PA, USA) were used in all patients. Sugita temporary clips (Mizuho Ika, Inc., Tokyo, Japan) were also used. During surgery, the patency of the distal and proximal arteries of the aneurysm was assessed using microvascular Doppler ultrasonography and/ or indocyanine green video angiography.

\section{MRI}

In all patients, MRI was performed $24 \mathrm{~h}-4$ days after the surgery because DWI or MRA conducted immediately after $A C$ may be affected by artifacts resulting from the surgical procedure, such as intracranial air or motion artifacts from the patient. Considering these facts, we scheduled DWI and MRA for 1-4 days after AC. In all patients, postoperative DWI and MRA were performed to detect ischemic complications due to thromboemboli or hypoperfusion, procedural ischemic complications or vasospasms of the MCA.We conducting MRI examinations using a 3.0T unit (Achieva 3T, Philips Medical Systems, Best, The Netherlands) with an 8-channel phased array head coil. DWI was performed using two-dimensional, single-shot, spin-echo, echo planar imaging of the entire brain with the following parameters: echo time (TE), 50; repetition time (TR), infinite; $B, 1000 \mathrm{~s} / \mathrm{mm}^{2}$; field of view (FOV), $24 \times 24$ $\mathrm{cm}$; flip angle, $90^{\circ}$; imaging matrix, $128 \times 128$; slice thickness, $5.5 \mathrm{~mm}$ with a $1.5-\mathrm{mm}$ gap; and number of slices, 20 . Threedimensional T1 fast field echo time-of-flight MRA of the circle of Willis was performed using the following parameters: flip angle, 18 ; TR, $25 \mathrm{~ms}$; TE, $3.5 \mathrm{~ms}$; slice thickness, $1.2 \mathrm{~mm}$; FOV, $20 \times 20$; matrix size, $512 \times 205$; number of slices, $132-$ 160; slice gap, $0.6 \mathrm{~mm}$. DWI scans were evaluated by two experienced neuroradiologists and neurosurgeons. Any new hyperintensities observed using postoperative DWI were interpreted as new ischemic lesions that developed after AC. For radiological evaluations, all DWI and MRA scans were analyzed by at least two radiologists (RT, YA) or a neurosurgeon (YM) to detect any evidence of ischemia. In all cases, outcome of the patients on the modified Rankin scale (mRS) were evaluated at discharge and at 6 months post operatievely.

\section{RESULTS}

Postoperative DWI was performed $2.47 \pm 0.61$ days after AC (range, 1-4 days). In six patients, temporary clip occlusion of M1 was performed with an average duration of $148 \mathrm{~s}$ (range, 94-382 s). In seven patients, re-clipping was performed to change the first clip, and the duration of the first aneurysmal clip averaged 192 s (range, 118428 s). DWI revealed asymptomatic hyperintensities in the ipsilateral or contralateral hemispheres of three patients, and no symptomatic hyperintensities in the ipsilateral or contralateral hemispheres were observed after surgery. In addition, no asymptomatic ischemic hyperintensities were observed in the ipsilateral or contralateral hemispheres on DWI, and no symptomatic or asymptomatic stenosis or 
occlusion in the ipsilateral hemisphere was observed on MRA after surgery. In one patient, an asymptomatic lesion was most likely caused by a small contusion that occurred during dissection of an aneurysm attached to the brain surface. In two patients, asymptomatic cortical lesions were probably caused by small contusions due to lacerations of the open dura. In these three patients, temporary clipping or reclipping was not performed. Postoperative contusions of the insulae were confirmed in one of these three patients because of adequate detachment from the surrounding structure. No fixed ischemic neurologic deficits resulted from clipping of unruptured MCA aneurysms. Postoperative MRA revealed no abnormal stenosis, vasospasms or MCA occlusion. However, in all patients, flow deficits were detected in the aneurysms because of clip artifacts. Neurological outcomes using the mRS at discharge and 6 months after clipping are 0 in all patients. In one patient with 72 y.o. woman with an unruptured 8 mm MCA aneurysm, post operative symptomatic ipsilateral chronic subdural hematoma was treated with irrigation on 46th post operative day.

\section{ILLUSTRATIVE CASE}

The preoperative three-dimensional CTA of a 64-year-old woman suggested the presence of a 4-mm MCA aneurysm requiring surgery. After a frontotemporal craniotomy, a dural tear and brain contusion occurred on the frontal surface. A pterional approach revealed a broad-necked MCA aneurysm, which was clipped with Yasargil clips without temporary occlusion of the parent artery. Postoperative DWI performed on day 1 (Figure 1) after surgery revealed high-intensity regions on the frontal brain surface. Postoperative MRA (Figure 2) and three-dimensional CTA performed on day 7 after surgery confirmed patency of the MCA and the M1 and $M 2$ segments. The postoperative course of the patient was uneventful and without epileptic attacks, and she was subsequently discharged.

\section{DISCUSSION}

The main purpose of this study was to use high-resolution DWI to determine the risk of complications following clipping of MCA aneurysms. This was also the first study to use 3.0T DWI to examine ischemic complications after $A C$ of unruptured MCA aneurysms. Studies involving interventional coiling for cerebral aneurysms used DWI to demonstrate new small symptomatic and asymptomatic ischemic brain lesions $(4,6,7,8)$. However, to the best of our knowledge, no similar studies (17) have assessed the efficiency of highresolution DWI and MRA to clarify the mechanisms and risk rates of surgical complications after AC. Furthermore, in similar studies using $\mathrm{CT}(23,30)$, the locations of aneurysms were not discussed with regard to the differences in surgical risks. These results suggest that symptomatic and asymptomatic postoperative focal abnormalities observed on DWI, consistent with ischemia arising from clipping or short temporary occlusions, are very rare after AC of the MCA. In addition, asymptomatic postoperative abnormalities observed on DWI are relatively infrequent. In this study, no symptomatic ischemic or nonischemic hyperintensities were detected in the ipsilateral or contralateral hemispheres on DWI. In addition, no symptomatic or asymptomatic stenosis or occlusion was observed on MRA after ipsilateral or contralateral hemisphere surgery. The rate of silent postoperative ischemia was very low in our cohort. This small study from a single center is not necessarily representative of the results that can be expected following all $A C$ procedures; however, based upon our experience, AC proved to be a safe procedure.

\section{Mechanisms of Ischemia}

Wirth regard to the treatment for cerebral aneurysms, Grunwald et al. (13) reported the incidence of ischemic complications after endovascular surgery for unruptured aneurysms in a DWI study. Postprocedural new lesions
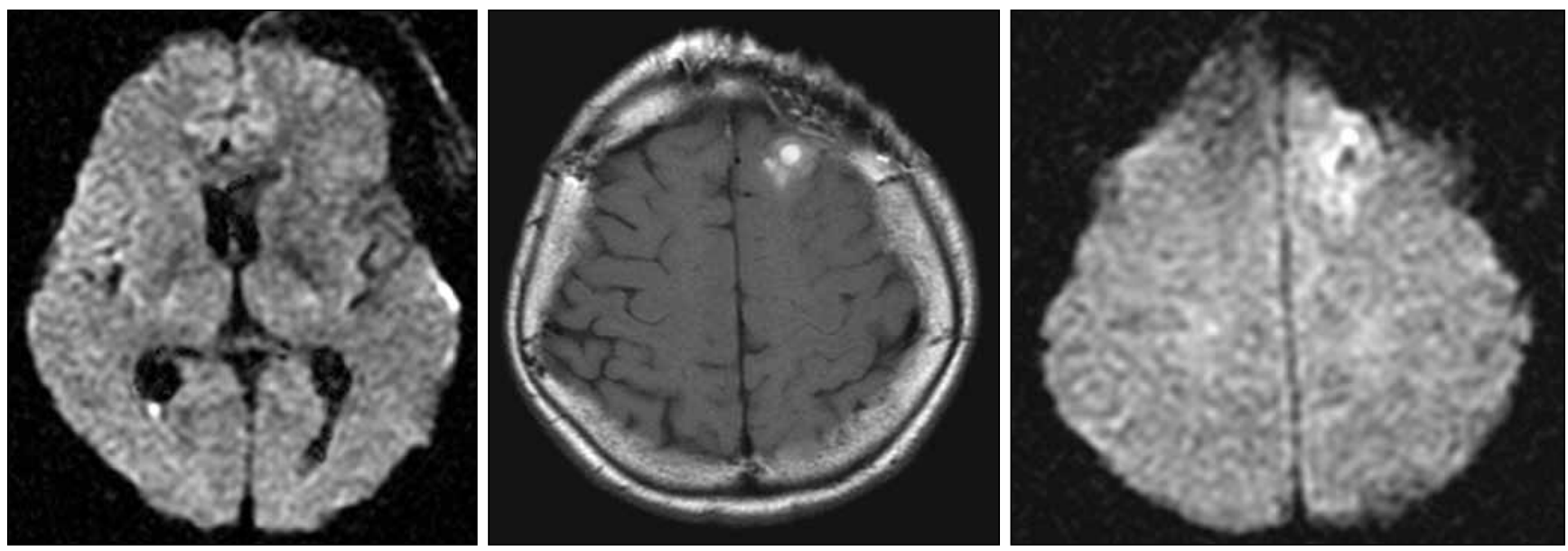

Figure 1: Postoperative brain diffusion-weighted imaging (DWI) in a 64-year-old woman with a left middle cerebral artery aneurysm. DWI(right) and T1 (middle) demonstrates a single new hyperintense lesion in the ipsilateral frontal cortical surface. This lesion was compatible with an area affected by a surgical contusion occurring intraoperatively. DWI (right and left) demonstrating no ischemic legion. 


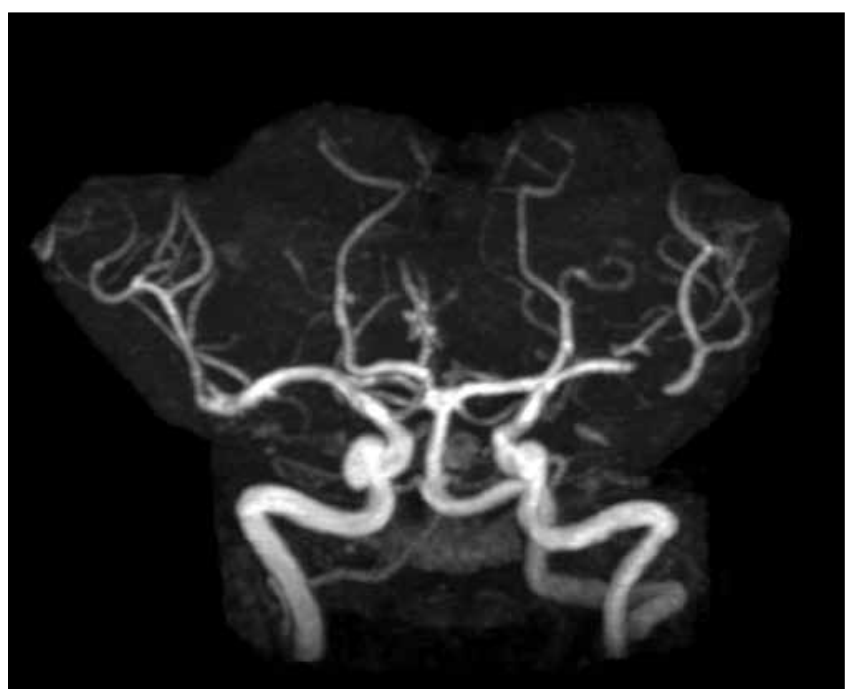

Figure 2: Postoperative brain magnetic resonance angiography demonstrating novascular stenosis of the carotid artery and the middle cerebral artery. A signal deficit is shown at the middle cerebral artery aneurysm lesion. However, M1 and M2 segment of the middle cerebral artery were clearly visible in a 3.0-Tesla image.

occurred in 21 of 50 (42\%) patients. Rordorf et al. (26) reported an incidence of $54 \%$ in 154 intravascular surgeries. However, Grunwald et al (13) and Rordorf et al (26). did not provide details of their MRI protocols in their reports. In a series of 36 patients ( 25 patients with unruptured aneurysms and 11 with ruptured aneurysms) with 51 aneurysms treated by AC, Krayenbühl et al. (17) observed new hyperintense areas on DWI within $24 \mathrm{~h}$ of $\mathrm{AC}$ in six patients. This finding (17) represents a $9.8 \%$ incidence of silent postoperative highintensity areas (HIAs) per treated aneurysm and a $2 \%$ risk of symptomatic postoperative HIAs. However, Krayenbühl et al. (17). also did not provide details of their MRI protocol in their report. Of six patients in their study, one presented new temporary neurological deficits, and only one suffered transient aphasia with no abnormalities on DWI. Krayenbühl et al. (17). also reported that the risk of ischemic findings using abnormalities observed on DWI was statistically significant. Age, the presence of thrombi, the number of final clips, the number of temporary clips and the total duration of temporary clipping were significant, while the presence of SAH was not.

In recent studies (7.25), the incidence of ischemic findings on DWI after intravascular surgery was far greater for aneurysms treated for acute SAH $(30 \%-45 \%)$ than for unruptured aneurysms (4.6\%-61\%). Cronqvist Metal. (10) reported on DWI performed in conjunction with 43 interventional procedures in 40 patients (14 ruptured and 26 unruptured). Postprocedural DWI abnormalities were small $(<3 \mathrm{~mm})$, ipsilateral to the treated aneurysm and asymptomatic in $92.5 \%$ patients (37 of 40 patients) (10). Periprocedural complications occurred in $23 \%$ procedures (10 of 43 ). Ruptured cases accounted for $67 \%$ lesions, whereas unruptured cases accounted for $33 \%$ lesions.
Brooks et al (7) also reported on DWI of 155 aneurysms in 132 patients. Small DWI abnormalities were present in 24\% (37 / 155 aneurysm lesions). Furthermore, 68\% (25 of 37) lesions positive on DWI were cases of rupture. Symptomatic ischemic complications were present in $27 \%$ (10 of 37) lesions, with $70 \%$ (7 of 10) of being case of ruptured aneurysm. Bracard et al (6) reported a retrospective analysis of a consecutive series of 152 MCA aneurysms (73 ruptured) treated by endovascular coiling in 140 patients. Procedure-related complications included 13 thromboembolic events [8.6\%; 10 of 73 ruptured (13.7\%) and 3 of 79 unruptured $(3.8 \%)$ aneurysms]. The total occlusion rate of unruptured MCA aneurysms was $31 \%$ in their study (6). These differences in DWI findings between unruptured and ruptured aneurysms are interesting $(7,10,14)$. One possible reason for this disparity is acute vasospasms that occur after $\mathrm{SAH}(6,7,10,14,31,33)$. Another can be periprocedural antiplatelet/anticoagulation therapy $(6,7,10,14)$. Because of these possible influences, we selected unruptured or delayed-phase ruptured aneurysms to evaluate the technical ischemic complications of AC. This study represented a $7.7 \%$ incidence of silent postoperative HIA per treated aneurysm and a $0 \%$ risk of symptomatic postoperative HIA. These slight HIAs were very faint and caused by surgical procedures and brain contusions due to dissection of the aneurysmal dome attached to the brain surface. Therefore, the risk of symptomatic and asymptomatic ischemic complications after $A C$ of unruptured intracranial MCA aneurysms appears to be low. There is a difference in the risk of diffusion abnormalities, caused by aneurysm location and $\mathrm{SAH}$. To analyze the incidence of surgical complications, it is important to examine similar patients. Samson et al (30) concluded that patients with aneurysms located in arterial segments that give rise to perforating vessels demonstrated poor tolerance to long durations of occlusion. In addition, they (30) reported infarction rates of $41 \%$ for the basilar artery and $26 \%$ for the MCA, in contrast to $16 \%$ for the anterior cerebral artery and 7\% for the ICA. These studies used CT scanning. Had they used MRI, particularly DWI, the ischemia rate would have been higher. The authors $(23,25,30)$ of these studies suggested safe occlusion durations of 10-15 min. Using these temporary occlusion protocols, the infarction rate has varied with a mean of $15 \%-20 \%$. Samson et al (30) demonstrated that the risk of ischemic complications differed according to location. In addition, the adequacy of collateral perfusion through the posterior communicating artery and/ or anterior communicating artery was completely different for each patient. Mizoi (23) and Symon et al. (32) performed an somatosensory evoked potential (SSEP) study of temporary occlusion of the parent artery and reported that sufficient collateral perfusion was maintained through the posterior communicating artery and/or anterior communicating artery when only the parent ICA, and not the MCA, was occluded. In addition, there may be many causes $(14,17,20,24)$ other than temporary clipping or permanent clipping that may be related to the incidence of abnormalities observed on DWI after $A C$, such as brain retraction by spatula or brain contusion. There are not many differences in surgical techniques 
or approaches for unruptured MCA aneurysms between institutes. Furthermore, in our institute, all MCA aneurysms are treated with surgical strategies without interventional treatment; therefore, there was no question of treatmentselection bias related to intravascular surgery or AC in this study. Mechanisms underlying ischemic complications after AC for acute-phase SAHs from a partially thrombosed and/or large aneurysm are far more complex than those after AC for small unruptured MCA aneurysms $(16,17,23,24)$. After acutephase surgery, vasospasm or direct brain injury from SAH may occur, as reported by Hadeishi et al. (14). as well as by other authors $(9,31)$ who performed DWI after surgery for SAHs. Rordorf et al. (26) and Condette-Aulian et al. (9) suggested that DWI can diagnose the early stages of symptomatic vasospasms. Hadeishi et al. (14) found multiple lesion sites in the cerebral cortex of patients with poor-grade acute SAH using preoperative DWI. As described, AC for ruptured aneurysms associated with acute-phase SAH involves many risk factors that may lead to ischemic complications. For such reasons, AC of unruptured or delayed-phase ruptured MCA aneurysms is effective in the detection of ischemic complications of AC.

\section{REFERENCES}

1. Alshekhlee A, Mehta S, Edgell RC, Vora N, Feen E, Mohammadi A, Kale SP, Cruz-Flores S: Hospital mortality and complications of electively clipped or coiled unruptured intracranial aneurysm. Stroke 41:1471-1476, 2010

2. Alvarez-Linera J: $3 T$ MRI: Advances in brain imaging.Eur J Radiol 67:415-426, 2008

3. Araki Y, Andoh H, Yamada M, Nakatani K, Andoh T, Sakai N: Permissible arterial occlusion time in aneurysm surgery: Postoperative hyperperfusion caused by temporary clipping. Neurol Med Chir (Tokyo) 39:901-907, 1999

4. Asakura F, Kawaguchi K, Sakaida H, Toma N, Matsushima S, Kuraishi K, Tanemura H, Miura Y, Maeda M, Taki W: Diffusionweighted magnetic resonance imaging in carotid angioplasty and stenting with balloon embolic protection devices. Neuroradiology 48:100-112, 2006

5. Bendszus $M$, Koltzenburg $M$, Burger $R$, Warmuth-Metz $M$, Hofmann E, Solymosi L: Silent embolism in diagnostic cerebral angiography and neurointerventional procedures: A prospective study. Lancet 354:1594-1597, 1999

6. Bracard $S$, Abdel-Kerim A, Thuillier L, Klein O, Anxionnat R, Finitsis S, Lebedinsky A, de Freitas CM, Pinheiro N, de Andrade GC, Picard L: Endovascular coil occlusion of 152 middle cerebral artery aneurysms: Initial and midterm angiographic and clinical results. J Neurosurg 112:703-708, 2010

7. Brooks NP, Turk AS, Niemann DB, Aagaard-Kienitz B, Pulfer $\mathrm{K}$, Cook T: Frequency of thromboembolic events associated with endovascular aneurysm treatment: Retrospective case series. J Neurosurg 108:1095-1100, 2008

8. Chung SW, Baik SK, Kim Y, Park J: Thromboembolic events after coil embolization of cerebral aneurysms: Prospective study with diffusion-weighted magnetic resonance imaging follow-up. J Korean Neurosurg Soc 43:275-280, 2008
9. Condette-Auliac S, Bracard S, Anxionnat R, Schmitt E, LacourJC, Braun M, Meloneto J, Cordebar A, Yin L, Picard $\mathrm{L}$ : Vasospasm after subarachnoid hemorrhage: Interest in diffusion-weighted MR imaging. Stroke 32:1818-1824, 2001

10. Cronqvist M, Wirestam R, Ramgren B, Brandt L, Nilsson O, Säveland $\mathrm{H}$, Holtås $\mathrm{S}$, Larsson EM: Diffusion and perfusion MRI in patients with ruptured and unruptured intracranial aneurysms treated by endovascular coiling: complications, procedural results, MR findings and clinical outcome. Neuroradiology 47:855-873, 2005

11. Faraglia V, Palombo G, Stella N, Rizzo L, Taurino M, Bozzao A: Cerebral embolization during transcervical carotid stenting with flow reversal: A diffusion-weighted magnetic resonance study. Ann Vasc Surg 23: 429-435, 2009

12. Fries $P$, Runge $V M$, Kirchin $M A$, Stemmer $A$, Naul LG, Wiliams KD, Reith W, Bücker A, Schneider G: Diffusion-weighted imaging in patients with acute brain ischemia at $3 \mathrm{~T}$ : Current possibilities and future perspectives comparing conventional echoplanar diffusion-weighted imaging and fast spin echo diffusion-weighted imaging sequences using BLADE (PROPELLER). Invest Radiol 44:351-359, 2009

13. Grunwald IQ, Papanagiotou P, Politi M, Struffert T, Roth C, Reith W: Endovascular treatment of unruptured intracranial aneurysms: Occurrence of thromboembolic events. Neurosurgery 58:612-618, 2006

14. Hadeishi H, Suzuki A, Yasui N, Hatazawa J, Shimosegawa E: Diffusion-weighted magnetic resonance imaging in patients with subarachnoid hemorrhage. Neurosurgery 50:741-748, 2002

15. Kosior RK, Wright CJ, Kosior JC, Kenney C, Scott JN, Frayne R, Hill MD: 3-Tesla versus 1.5-Tesla magnetic resonance diffusion and perfusion imaging in hyperacute ischemic stroke. Cerebrovasc Dis 24:361-368, 2007

16. Kosior RK, Hill MD, Frayne R: Less could be more when it comes to diffusion imaging of acute stroke. Neurology 74:1936-1937, 2010

17. Krayenbühl N, Erdem E, Oinas M, Krisht AF: Symptomatic and silent ischemia associated with microsurgical clipping of intracranial aneurysms: Evaluation with diffusion-weighted MRI. Stroke 40:129-133, 2009

18. Kuhl CK, Textor J, Gieseke J, von Falkenhausen M, Gernert S, Urbach $\mathrm{H}$, Schild $\mathrm{HH}$ : Acute and subacute ischemic stroke at high-field-strength (3.0-T) diffusion-weighted MR imaging: Intraindividual comparative study. Radiology 234:509-516, 2005

19. Lauzon ML, Sevick RJ, Demchuk AM, Frayne R: Stroke imaging at 3.0 T. Neuroimaging. Clin N Am 16:343-366, 2006

20. Lavine SD, Masri LS, Levy ML, Giannotta SL: Temporary occlusion of the middle cerebral artery in intracranial aneurysm surgery: Time limitation and advantage of brain protection. J Neurosurg 87:817-824, 1997

21. Lövblad KO, Yilmaz $H$, Chouiter A, San Millan Ruiz D, Abdo G, Bijlenga $P$, de Tribolet $N$, Ruefenacht DA: Intracranial aneurysm stenting: Follow-up with MR angiography. J Magn Reson Imaging 24:418-422, 2006 
22. Mirow N, Zittermann A, Körperich $\mathrm{H}$, Börgermann J, Koertke H, Knobl H, Gieseke J, Ostertun B, Coskun T, Kleesiek K, Burchert W, Gummert JF: Diffusion-weighted magnetic resonance imaging for the detection of ischemic brain lesions in coronary artery bypass graft surgery: Relation to extracorporeal circulation and heparinization. J Cardiovasc Surg (Torino) 52:117-126, 2011

23. Mizoi K, Yoshimoto T: Permissible temporary occlusion time in aneurysm surgery as evaluated by evoked potential monitoring. Neurosurgery 33:434-440, 1993

24. Nussbaum ES, Madison MT, Myers ME, Goddard J: Microsurgical treatment of unruptured intracranial aneurysms. A consecutive surgical experience consisting of 450 aneurysms treated in the endovascular era. Surg Neurol 67:457-466, 2007

25. Ogawa A, Sato $H$, Sakurai $Y$, Yoshimoto $T$ : Limitation of temporary vascular occlusion during aneurysm surgery. Study by intraoperative monitoring of cortical blood flow. Surg Neurol 36:453-457, 1991

26. Rordorf G, Koroshetz WJ, Copen WA, Gonzalez G, Yamada K, Schaefer PW, Schwamm LH, Ogilvy CS, and Sorensen AG: Diffusion- and perfusion-weighted imaging in vasospasm after subarachnoid hemorrhage. Stroke 30:599-605, 1999

27. Rordorf G, Bellon RJ, Budzik RE Jr, Farkas J, Reinking GF, Pergolizzi RS, Ezzeddine M, Norbash AM, Gonzalez RG, Putman CM: Silent thromboembolic events associated with the treatment of unruptured cerebral aneurysms by use of Guglielmi detachable coils: Prospective study applying diffusion-weighted imaging. AJNR 22:5-10, 2001

28. Rosenkrantz AB, Oei M, Babb JS, Niver BE, Taouli B: Diffusionweighted imaging of the abdomen at 3.0 Tesla: Image quality and apparent diffusion coefficient reproducibility compared with 1.5 Tesla. J Magn Reson Imaging 33:128-135, 2011

29. Rosso C, Drier A, Lacroix D, Mutlu G, Pires C, Lehéricy S, Samson Y, Dormont D: Diffusion-weighted MRI in acute stroke within the first 6 hours: 1.5 or 3.0 Tesla? Neurology 15:1946-1953, 2010
30. Samson D, Batjer HH, Bowman G, Mootz L, Krippner WJ Jr, Meyer YJ, Allen BC: A clinical study of the parameters and effects of temporary arterial occlusion in the management of intracranial aneurysms. Neurosurgery 34:22-29, 1994

31. Siironen J, Porras M, Varis J, Poussa K, Hernesniemi J, Juvela S: Early ischemic lesion on computed tomography: Predictor of poor outcome among survivors of aneurysmal subarachnoid hemorrhage. J Neurosurg 107: 1074-1079, 2007

32. Symon L, Wang AD, Costa e Silva IE, Gentill F: Perioperative use of somatosensory evoked responses in aneurysm surgery. J Neurosurg 60: 269-275, 1984

33. Szelényi A, Beck J, Strametz R, Blasel S, Oszvald A, Raabe A, Seifert V: Is the surgical repair of unruptured atherosclerotic aneurysms at a higher risk of intraoperative ischemia? Clin Neurol Neurosurg 113: 129-135, 2010

34. Taha MM, Maeda M, Sakaida H, Kawaguchi K, Toma N, Yamamoto A, Hirose T, Miura Y, Fujimoto M, Matsushima S, Taki W: Cerebral ischemic lesions detected with diffusionweighted magnetic resonance imaging after carotid artery stenting: Comparison of several anti-embolic protection devices. Neurol Med Chir (Tokyo) 49:386-393, 2009

35. Wasser K, Pilgram-Pastor SM, Schnaudigel S, Stojanovic T, Schmidt H, Knauf J, Gröschel K, Knauth M, Hildebrandt H, Kastrup A: New brain lesions after carotid revascularization are not associated with cognitive performance. J Vasc Surg 53:61-70, 2011

36. Wiebers DO, Whisnant JP, Huston J 3rd, Meissner I, Brown RD Jr, Piepgras DG, Forbes GS, Thielen K, Nichols D, O'Fallon WM, Peacock J, Jaeger L, Kassell NF, Kongable-Beckman GL, Torner JC: International Study of Unruptured Intracranial AneurysmsInvestigators. Unruptured intracranial aneurysms: Natural history, clinical outcome, and risks of surgical and endovascular treatment. Lancet 362:103-110, 2003 